\title{
Kredibilitas Influencer dalam Membentuk Kepercayaan Konsumen terhadap Brand
}

\author{
Rifqi Adrianto
}

Prodi Advertising Comunication, Sekolah Tinggi Ilmu Komunikasi Interstudi, Indonesia.

Rifqiadrianchd@mail.com

\begin{abstract}
Advertising and promotion campaigns often involve influencers to deliver messages through the media to increase consumer trust in the brand. In addition, influencers have a level of credibility which has an impact on the level of trust in the brand. Zilingo is one of the fashion e-commerce brands on the online platform, which also takes advantage of influencers' credibility in their advertising campaign strategy. However, in entering the eMarket Platform, Zilingo as a new E-commerce platform is required to be able to build brand trust in order to compete with e-commerce brands that have previously existed as market leaders. Establishing trust in a brand is very important because Brand Trust is the main consideration for consumers to buy products. The research has several variables, namely Trustworthiness, Expertise, Similarity, Attractiveness as the independent variable and Brand Trust as the dependent variable. This research uses a quantitative approach and a positivist paradigm based on observations of social realities that occur. The research population is Zilingo consumers. The data collection technique is done by using non probability sampling. Based on the calculation of the sample formula, it is known that the number of samples in this study was 100 respondents. The results showed that Trustworthiness, Expertise, Similarity, Attractiveness had a significant positive effect on Brand Trust.
\end{abstract}

Keywords: Trustworthiness, Expertise, Similarity, Attractiveness, Brand Trust

\begin{abstract}
Abstrak. Kampanye periklanan dan promosi seringkali melibatkan influencer untuk mengantarkan pesan melalui media guna meningkatkan kepercayaan konsumen terhadap brand. Selain itu, Influencer memiliki tingkat kredibilitas yang berdampak pada tingkat kepercayaan terhadap brand. Zilingo merupakan salah satu fashion e-comerce brand pada Platform online, yang juga memanfaatkan kredibilitas influencer dalam strategi kampanye iklannya. Namun, dalam memasuki eMarket Platform, Zilingo sebagai new E-comerce dituntut mampu membangun kepercayaan brand agar dapat bersaing dengan e-comerce brand yang telah lebih dahulu ada sebagai market leader. Membentuk kepercayaan terhadap brand merupakan hal yang sangat penting karena Brand Trust menjadi pertimbangan utama konsumen untuk membeli produk. Dalam penelitian memiliki beberapa Variable yaitu Trustworthiness, Expertise, Similarity, Attractiveness sebagai Variable independent dan Brand Trust sebagai Variable dependent. Dalam penelitian ini digunakan pendekatan kuantitatif dan paradigma positivism berdasarkan pengamatan terhadap realitas sosial yang terjadi. Populasi penelitian yaitu konsumen Zilingo. Teknik pengumpulan data dilakukan dengan non probability sampling. Berdasarkan perhitungan rumus sampel diketahui bahwa jumlah sampel penelitian ini adalah 100 responden. Hasil penelitian menunjukkan bahwa Trustworthiness, Expertise, Similarity, Attractiveness memiliki pengaruh positif yang signifikan terhadap Brand Trust.
\end{abstract}

Kata Kunci: : Trustworthiness, Expertise, Similarity, Attractiveness, Brand Trust. 


\section{A. Pendahuluan}

Dalam periklanan, Influencer menyebarkan pesan-pesan persuasif yang mengandung nilai informasi (melalui uduhan terkait alternatif produk atau konten informasi lainnya) dengan sentuhan estetika pribadi yang menciptakan pengalaman menyenangkan bagi pengikutnya (Lou, 2019). Influencer tidak hanya harus menarik, tetapi juga harus memiliki kredibilitas dan pemahaman terkait produk dari brand yang dikomunikasikan (Hill, 2018).

Pada umumnya daya tarik influencer dalam iklan dapat bersifat logis dan emosional sehingga influencer yang representatif dianggap lebih efektif dalam menjangkau serta membujuk konsumen segala kalangan (Schiffman, 2008). Representasi influencer tersebut mencakup aspek integritas (Trustworthiness), ketrampilan, pengetahauan (Expertise), atraktifitas karakteristik (Atractiveness) serta kedekatan kesamaan (Similarity) dengan konsumen. Sehingga para pemilik brand bersedia membayar mahal untuk Influencer yang disukai dan disegani khalayak karena secara tidak langsung influencer yang dianggap relevan akan mempengaruhi perilaku konsumen terhadap produk yang di iklankan (Shimp, 2003).

Influencer telah menjadi cara yang sangat tepat dan efektif dalam membina hubungan yang kuat antara brand dengan konsumennya (Hamalainen, 2016). Influencer berkontribusi pada hubungan konsumen dan merek (Schouten, A. P., L. Janssen, 2019). Setiap Influencer memiliki efektifitas yang bervariasi sehingga pemilihan influencer yang memiliki kesesuaian dengan brand menjadi tantangan yang tidak mudah bagi pemilik brand (De Veirman, M., V. Cauberghe, 2017).

Influencer cenderung mendapat tingkat kepercayaan yang lebih tinggi di media sosial dalam mengkomuikasikan produk ataupun brand yang relatif baru (Kumar, H., M. K. Singh, 2018). Influencer dalam komunikasi pemasaran merek dapat diartikan dengan sebagai sumber yang memiliki "pengaruh", yaitu seseorang yang memiliki pengetahuan, pemahaman dan daya tarik serta mampu memberi dampak pada orang lain (Cambridge Dictionary, 2018).

Penggunaan influencer dipandang sangat efektif dalam membina hubungan yang kuat antara Brand dengan Konsumen (Hamalainen, 2016). Influencer dapat meneruskan informasi dan membentuk kepercayaan terhadap brand itu sendiri (Brown, D., Fiorella, 2013).

Dalam membangun kepercayaan merek melalui Influencer, tingkat Kredibilitas seorang Influencer dapat dinilai dari empat komponen di antaranya trustworthiness, expertiseness, similarity, and attractiveness. Empat komponen tersebut menjadi bagian penting yang harus dimiliki seorang influencer marketing. Hal ini juga dapat dinilai dari kecocokan antara Influencer marketing dengan brand yang di bawa nya (misalnya, faktor demografis atau ideologis) (Munnukka, Juha, Outi Uusitalo, 2016). Influencer memiliki tingkat kredibilitas yang berbeda beda, yang juga berdampak pada tingkat kepercayaan konsumen yang timbul terhadap brand (Hall, 2015).

Membentuk kepercayaan terhadap brand sangat penting karena saat ini brand berevolusi dari fungsional (membuat atribut produk, kualitas produk, nilai, kenyamanan, dan kandungan produk) ke kepercayaan (kepercayaan terhadap brand menjadi pertimbangan utama untuk membeli produk) (Edelman Trust Barometer, 2019). Delapan puluh persen (80\%) konsumen mengaitkan pembelian dengan pertimbangan yang secara historis terkait dengan kepercayaan pada brand (Edelman Trust Barometer, 2019).

Kepercayaan konsumen terhadap brand (Brand trust) dapat diartikan bahwa konsumen pada umumnya bersedia untuk mengandalkan kemampuan sebuah merek dalam menjalankan fungsinya untuk memenuhi ekspektasi kinerja merek tersebut sesuai dengan harapan positif konsumen (Portal, S., Abratt, R., \& Bendixen, 2019).

Zilingo merupakan salah satu new comerce brand pada eMarket Platform online yang menggunakan kredibilitas influencer sebagai Key Opinion Leader dalam strategi kampanye iklannya (Saviq Bachdar, 2018). Namun, dalam memasuki eMarket Platform Zilingo harus mampu membangun kepercayaan brandnya untuk dapat bersaing dengan brand yang telah lebih dahulu ada sebagai market leader. 


\section{B. Landasan Teori}

Influencer Credibility merupakan individu yang memiliki kapabilitas atau kekuatan untuk mempengaruhi orang lain melalui karakteristiknya (Shimp, 2003). Pada umumnya Influencer berperan dalam tiga hal utama untuk meningkatkan tingkat kredibilitasnya atau pada saat sedang melakukan kegiatan komunikasi pemasaran. Tiga Peran utama tersebut diantaranya adalah to inform, to persuade, dan to entertain.

Fungsi to inform dalam hal ini Influencer marketing berperan untuk menginformasikan tentang suatu brand kepada audience dengan tujuan untuk meningkatkan brand trust sehingga audience tertarik, kemudian to persuade dimana seorang influencer berperan untuk meyakinkan audience untuk menerima sudut pandangnya atau meminta untuk mengadopsi perasaan dan perilakunya. Sedangkan yang terakhir to entertain; seorang influencer marketing berperan dalam menghibur audience sehingga konten yang di bawa oleh inflluencer marketer tersebut yang bersifat persuasif dan pesan yang ingin disampaikan dari brand dapat diterima dengan baik oleh audience (Sugiharto, S.A. dan M. R. Ramadhana, 2018).

Influencer Marketing adalah strategi Komunikasi periklanan yang digunakan sebagai individu kunci atau pemimpin opini untuk mendorong Kepercayaan merek atau Brand Trust (Scott, 2015).Seorang influencer marketing akan mendapatkan pengakuan dari publik apabila memiliki suatu keahlian yang membuat mereka menjadi dikenal dan juga dapat meningkatkan tingkat kredibilitas influencer marketing-nya, sehingga hal ini dapat mempermudah seorang influencer dalam melakukan kegiatan komunikasi pemasaran produk atau brand (Alexander P. Schouten, Loes Janssen \& Maegan Verspaget, 2020).

Influencer memiliki peran yang jauh berbeda dengan Selebriti yang hanya fokus untuk menghibur. Influencer berperan tidak hanya untuk menghibur tetapi juga untuk menginformasikan, memberi edikasi atau pengetahuan serta mempersuasi audiens (Jiang, 2018). Kredibilitas influencer dapat dinilai dari cara mereka mempublikasikan diri melalui lifestyle, maupun daily activity terhadap followers yang dimiliki untuk memperluas relasi, link atau koneksi kemudian memperoleh reward atau awards serta terbina hubungan yang lebih dekat dengan pengikutnya. (Deatara E. Z. Karouw, Frederik G. Worang, 2019).

Influencer dapat mengutarakan minat pribadinya terhadap suatu produk atau brand. Namun, yang lebih penting adalah bagaimana influencer dapat menggunakan kredibilitasnya sehingga audiens mereka dapat memiliki minat dan kepercayaan yang sama terhadap brand (brand trust) yang dikomunikasikan oleh influencer (Jiang, 2018). Influencer Marketing adalah seorang individu yang dapat mempengaruhi konsumen lain melalui penyebaran informasi, sikap, dan dukungan (Sigala, 2017)

Konsep umum dari Influencer terdiri atas Trustworthiness yang mengacu pada kemampuan untuk dipercaya, kejujuran, serta integritas dari celebrity. Selanjutnya yaitu Expertiseness yang mengacu pada pengetahuan, pengalaman, atau keterampilan yang dimilki oleh seorang Influencer. Selain kedua hal tersebut Attractiveness juga menjadi konsep berikutnya yaing mengacu pada sejumlah karakteristik fisik yang dapat dilihat orang dalam diri Influencer tersebut, misalnya ketampanan atau kecantikan, keatletisan tubuh, dan lain sebagainya. Sedangkan konsep terakhir yaitu Similarity, merupakan atribut yang penting karena lebih mudah bagi konsumen untuk berhubungan dengan seorang influencer yang memiliki karakteristik yang sama dengan diri konsumen tersebut (Shimp, 2003).

Influencer memiliki efektifitas yang bervariasi sehingga brand harus memperhitungkan kecocokan (similarity) influencer dengan brand (De Veirman, M., V. Cauberghe, 2017). Berdasarkan uraian tersebut, maka dapat dihipotesiskan bahwa :

1. H1 : Trustworthiness berpengaruh positif terhadap Brand Trust

2. H2 : Expertiseness berpengaruh positif terhadap Brand Trust

3. H3 :Similarity berpengaruh positif terhadap Brand Trust

4. H4 : Attractiveness berpengaruh positif terhadap Brand Trust

\section{Metode}

Dalam penelitian ini digunakan pendekatan kuantitatif dan paradigma positivism berdasarkan 
pengamatan terhadap realitas sosial yang terjadi (Kusuma dan Prasetio, 2016).

ini adalah 100 responden.

Keseluruhan variabel diukur dengan mengadopsi skala item (Lou, 2019) meliputi 4 item pertanyaan variabel Trustwortiness, 4 item pertanyaan variabel Expertiseness, 3 item pertanyaan variabel Similarity dan 4 pertanyaan pertanyaan variabel Attractivenes. Data kemudian diuji dan dianalisis mengguankan metode Structural Equation Model (SEM) dan Partial Least Square (PLS).

\section{Hasil Penelitian dan Pembahasan}

Seluruh responden dalam penelitian ini yang merupakan Konsumen serta Followers Sosial Media Zilingo menunjukan data diantaranya yang berusia 14-17 tahun sebanyak 2\%, lalu usia 18-24 tahun sebanyak 54\% yang merupakan usia mayoritas Konsumen serta followers Zilingo, kemudian usia 25-29 tahun sebanyak 37\% dan yang terakhir usia 29 keatas sebanyak 7\%.

Setelah Itu Konsumen serta Followers Zilingo terbagi menjadi 2 Gender dimana Perempuan menjadi dominasi sebanyak $61 \%$ dan Pria sebanyak 39\%. Kemudian terbagi menjadi 3 Regional dimana Konsumen dan followers Zilingo di daerah Jabodetabek mendominasi sebanyak 65\% lalu 34\% dari luar Jabodetabek dan 1\% dari region lainya. Dari hasil data quesioner juga menunjukan hasil bahwa Konsumen serta followers Zilingo juga memiliki kebiasaan durasi waktu menggunakan sosial media dalam sehari, diantaranya sebanyak 49\% responden menggunakan Social media dalam sehari selama 5-7 jam, lalu diikuti Responden yang menggunaakan Sosial media lebih dari 7 jam sebannyak $25 \%$, kemudian $24 \%$ responden yang menggunakan sosial media selama 2-4 jam dan sisa nya sebanyak $2 \%$ yang menggunakan sosial media kurang dari 2 jam dalam sehari.

Keberadaan Influencer yang digunakan oleh Zilingo memberikan beberapa alasan mengapa Konsumen serta Followers Zilingo ingin mengakses E-Commerce yang di dapat dari Data bahwa 39\% alasan ingin mengakses E-Commerce Zilingo "merasa Zilinggo memiliki influencer yang ahli dalam bidang fashion style", berikutnya $27 \%$ Responden memberikan alasan bahwa "Saya merasa Influencer Zilinggo Menarik". 22\% Responden berikutnya memberikan alasan "merasa influencer Zilinggo memiliki kesesuaian style / mewakili style saya". Sisanya Sebanyak 12\% Responden memberikan alasan bahwa "Influencer Zilinggo membuat saya yakin dengan Zilinggo"

Hasil penelitian ini menunjukkan bahwa nilai outer loading pada indikator setiap variabel memenuhi signifikansi diatas 0,7 dengan nilai Average Variance Extracted (AVE) > 0,5 sehingga dapat dipastikan bahwa seluruh indikator penelitian telah validi. Nilai Composite Reliability (CR) variabel penelitian juga telah melebihi nilai 0,6 yang mendukung reliabilitas konstruk sebagaimana ditunjukkan pada Tabel 1.

Tabel 1. Hasil Uji Validitas dan Reliabilitas

\begin{tabular}{|c|c|c|c|}
\hline Variable & Mean & $\begin{array}{c}\text { AVE } \\
(>0,50)\end{array}$ & $\begin{array}{c}\text { CR } \\
(>0,70)\end{array}$ \\
\hline TW & 4.340 & 0.289 & 2.456 \\
\hline EX & 4.392 & 0.201 & 1.695 \\
\hline SM & 4.186 & 0.320 & 3.026 \\
\hline AT & 4.497 & 0.230 & 2.760 \\
\hline $\begin{array}{l}\text { Note : } \\
\text { TW (Trustworthiness), EX (Expertise), SM } \\
\text { (Similarity), AT (Attractiveness ) }\end{array}$ \\
\hline
\end{tabular}


Sumber : Olah Data Penelitian 2021.

Hasil Koefisien Determinasi (R2) pada penelitian ini menunjukkan bahwa (66\%) kepercayaan konsumen terhadap brand (Brand Trust) secara kuat dijelaskan oleh variabel independennya, sedangkan sisanya (34\%) dijelaskan oleh variabel lain diluar penelitian ini.

Hasil pengujian hipotesis penelitian juga menunjukkan bahwa Trustworthiness, Expertise, Similarity, Attractiveness, terbukti signifikan mepengaruhi Brand Trust sebagaimana ditunjukkan pada Tabel 2.

Tabel 2. Hasil Uji Hipotesis

\begin{tabular}{|l|c|c|c|c|}
\hline Construct & Coefficient & T Statistic & P Values & Intepretation \\
\hline TW -->BT & 0.270 & 0.110 & $\mathbf{0 . 0 0 7}$ & Supported \\
\hline EX -->BT & 0.217 & 0.128 & $\mathbf{0 . 0 4 5}$ & Supported \\
\hline SM -->BT & 0.319 & 0.105 & $\mathbf{0 . 0 0 1}$ & Supported \\
\hline AT -->BT & 0.227 & 0.082 & $\mathbf{0 . 0 0 3}$ & Supported \\
\hline $\begin{array}{l}\text { Note : TW (Trustworthiness), EX (Expertise), SM (Similarity), AT } \\
\text { (Attractiveness), BT (Brand Trust), }\end{array}$ \\
\hline
\end{tabular}

Sumber : Olah Data Penelitian 2021.

Dari hasil pengujian model struktural dapat diketahui bahwa Similarity $(\beta=0.319)$ merupakan variabel yang paling dominan mempengaruhi Brand Trust dibanding dengan variabel lainnya. Influencer yang memiliki kesamaan dan kesesuaian dengan konsumen akan meningkatkan kepercayaan konsumen terhadap brand.

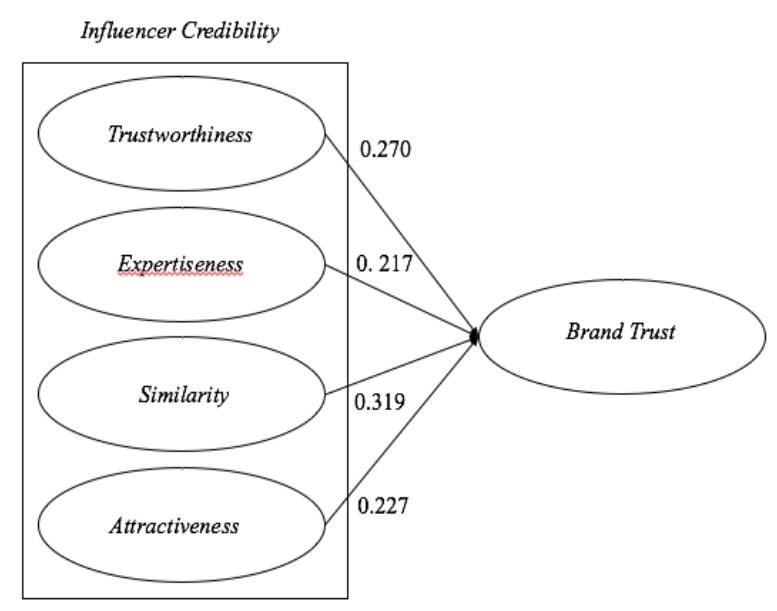

Gambar 1. Model Hasil Penelitian

(Sumber: Olah Data Penelitian 2021)

Trustworthiness dalam penelitian ini menjadi variabel kedua $(\beta=0.270)$ yang mempengaruhi Brand Trust. Audiens akan mediskusikan konten blog yang viral dalam kehidupan sehari-hari dengan orang lain (baik online maupun offline). Konsumen merasa influencer yang digunakan Zilingo memberikan informasi yang meyakinkan dan jujur sehingga mereka percaya dengan brand Zilingo.

Variabel ketiga yang mempengaruhi Brand Trust adalah Attractiveness $(\beta=0.227)$. Daya tarik influencer merupakan faktor yang membuat konsumen percaya dengan brand Zilingo. Sebaliknya, apabila influencer yang dipilih dianggap kurang menarik atau tidak 
menarik maka konsumen relatif kurang atau bahkan tidak percaya dengan brand Zilingo.

Expertiseness $(\beta=0.217)$ merupakan variabel keempat yang mempengaruhi Brand

Trust. Pengetahuan Influencer terkait produk dan kompetensinya dalam menjelaskan brand yang dikomunikasikan akan meningkatkan kepercayaan konsumen terhadap brand.

\section{Kesimpulan}

Penelitian ini memahami kredibilitas influencer yang dibangun melalui pendekatan Trustworthiness, Expertisness, Similarity dan Atractiveness dalam membentuk kepercayaan konsumen terhadap merek (Brand Trust).

Hasil penelitian menunjukkan bahwa kredibilitas influencer yang dibangun melalui pendekatan Trustworthiness, Expertisness, Similarity dan Atractiveness merupakan variabelvariabel yang secara positif mempengaruhi kepercayaan konsumen terhadap merek (Brand Trust) Zilingo. Apabila Zilingo ingin membangun kepercayaan konsumennya melalui kredibilitas influencer yang dipilih, maka Zilingo harus mampu memilih Influencer yang memiliki kesamaan dan kesesuaian profil dengan konsumen. Influencer yang dipilih Zilingo juga harus mampu memberikan informasi yang meyakinkan dan jujur sehingga konsumen akan percaya dengan brand Zilingo. Daya tarik influencer juga harus diperhitungkan sebagai faktor merupakan faktor yang membangun kepercayaan konsumen terhadap brand Zilingo. Selain ketiga f9aktor tersebut, Zilingo harus dapat memastikan bahwa Influencer yang dipilih memiliki pemahaman terkait produk dan memiliki kompetensi dalam menjelaskan brand yang dikomunikasikan.

Keempat faktor tersebut (Trustworthiness, Expertisness, Similarity dan Atractiveness) harus dijadikan sebagai dasar dalam menentukan kredibilitas Influencer yang dipilih sehingga konsumen memiliki kepercayaan kuat terhadap brand Zilingo:

\section{Daftar Pustaka}

[1]Alexander P. Schouten, Loes Janssen \& Maegan Verspaget. (2020). Celebrity vs. Influencer endorsements in advertising. International Journal of Advertising.

[2]Belch, George E. \& Belch, M. A. (2009). An Integrated Marketing Communications Perspective ((Eight Edi). Mc Graw - Hill.

[3]Brown, D., Fiorella, S. (2013). Influence Marketing. How to Create, Manage, and Measure Brand Influencers in Social Media Marketing. 1st ed. Indiana: Que Publishing.

[4]Cambridge Dictionary. (2018). $\quad$ No https://dictionary.cambridge.org/dictionary/english/influence

[5]Carnevale, M., Loureiro, Y.K., \& Kabadayi, S. (2018). (2018). Customer Value Creation for Risky Products: The Role of Brand Trust and Trusting Beliefs. Journal of Creating Value.

[6]De Veirman, M., V. Cauberghe, and L. H. (2017). Marketing through Instagram influencers: The impact of number of followers and product divergence on brand attitude. International Journal of Advertising 36 (5).

[7]Deatara E. Z. Karouw, Frederik G. Worang, M. H. C. P. (2019). Millennial Trust Through Endorser Credibility On Local Influencer Endorsement On Instagram.

[8]Edelman Trust $\quad$ Barometer, 2019. (2019). No Title. https://www.edelman.com/sites/g/files/aatuss191/files/201902/2019_Edelman_Trust_Barometer_Global_Report.pdf

[9]Hall, J. (2015). Build Authentic Audience Experiences through Influencer Marketing. Hamalainen, S. (2016). Vaikuttajamarkkinoinnin.

[10]Hill, A. 2018. (2018). Brand spokesperson smack down: Famous face vs. social media rockstar. https://www.business.com/articles/brand-spokesperson-influencer-vs-celebrity/

[11]Hot Social Media Influencer Trends for 2019: Micro-Influencers. (2019). https://castingasia.com/news/212/

[12]Indonesia Digital and Content Marketing Report. (2019). 
https://marketingcraft.getcraft.com/id-researches/indonesia-digital-content-marketingreport-2017

[13]Jiang, M. 2018. (2018). The Roles of Influencer Credibility and Inferences of Influencer Motives.

[14]Kumar, H., M. K. Singh, and M. P. G. 2018. (2018). Socio-influences of user generated content in emerging markets. Journal Marketing Intelligence and Planning. https://doi.org/10.1108/ MIP-12-2017-0347

[15]Kusuma dan Prasetio. (2016). Proses Public Relations PT. Pos Indonesia dalam Mempertahankan Citra Terkait Beredarnya Tabloid Obor Rakyat, Program Studi Ilmu Komunikasi , Fakultas Komunikasi dan Bisnis , Universitas Telkom Jl . Telkomunikasi Terusan Buah Batu , Bandung Jawa Barat 4025. 3(2), 2359-2368.

[16]Lou, Y. (2019). How Message Value and Credibility Affect Consumer Trust of Branded Content on Social Media. Journal of Interactive Advertising.

[17]Munnukka, Juha, Outi Uusitalo, and H. T. (2016). Credibility of a Peer Endorser and Advertising Effectiveness. Journal of Consumer Marketing, 182-92.

[18]Orzan et al., (2016). (2016). No Title. Conceptual Model Regarding the Influence of Social Media Marketing Communication on Brand Trust, Brand Affect and Brand Loyalty. https://www.researchgate.net/publication/323885394_Conceptual_model_regarding_the _influence_of_social_media_marketing_communication_on_brand_trust_brand_affect_ and_brand_loyalty

[19]Portal, S., Abratt, R., \& Bendixen, M. (2019). The role of brand authenticity in developing brand trust. Journal of Strategic Marketing.

[20]Saviq Bachdar. (2018). Siapa sih Zilingo. Marketeers.Com. https://marketeers.com/siapasih-zilingo/

[21]Schiffman, L. dan L. L. K. (2008). Perilaku Konsumen. Edisi Ketujuh.Jakarta.

[22]Schouten, A. P., L. Janssen, and M. V. (2019). Celebrity vs. influencer endorsements in advertising: The role of identification, credibility, and product-endorser fit. International Journal of Advertising 36 (5). https://doi.org/10.1080/02650487.2019.1634898

[23]Scott, D. M. (2015). How to Use Social Media, Online Video, Mobile Applications, Blogs, News Releases, and Viral Marketing to Reach Buyers Directly, Hoboken,. The New Rules of Marketing and PR, NJ: John Wiley.

[24]Shimp, T. A. 2003. (2003). Periklanan Promosi dan Aspek Tambahan Komunikasi Pemasaran Terpadu.

[25]Jurnal Manajemen Pemasaran.

[26]Sigala. (2017). No Title. Advances in Social Media for Travel, Tourism and Hospitality: New Perspectives, Practice and Cases, California.

[27]Sugiharto, S. A., M. R. R. (2018). Pengaruh Kredibilitas Influencer terhadap Sikap pada Merek. Jurnal Ilmu Politik Dan Komunikasi 